\title{
Colonisation of the Rhine basin by non-native gobiids: an update of the situation in France
}

\author{
S. Manné(1), N. Poulet ${ }^{(1)}$, S. Dembski(1), ${ }^{(1)}$ \\ Received October 23, 2012 \\ Revised July 19, 2013 \\ Accepted July 22, 2013
}

Key-words:

Proterorhinus

semilunaris,

Neogobius

melanostomus,

Ponticola

kessleri,

invasive species,

Rhine basin

\section{ABSTRACT}

Three of the four species of non-native gobiids currently reported in the Rhine basin were recently recorded in France: the Western tubenose goby in 2007, the bighead goby in 2010 and the round goby in 2011. The bighead goby and the round goby displayed a very high rate of range expansion, suggesting a human-assisted colonisation through inland navigation. An assessment of the invasiveness potential by the FISK (Fish Invasiveness Screening Kit) reveals a medium risk for the Western tubenose goby, while the bighead goby and the round goby are at high risk of becoming invasive in France. This assessment is consistent with our observations since there has been a steady increase in the range of the Western tubenose goby, although in low numbers, while the relative abundance of bighead goby and round goby, recently arrived in the French part of the Rhine River and Moselle River, can be high. Given their fast expansion, it can be assumed that these species will soon reach other French basins, particularly in the south (Rhône basin) and in the west (Seine basin), and the implementation of measures to limit their spread should be considered.

\section{RÉSUMÉ}

Colonisation du bassin du Rhin par les gobiidés non natifs : actualisation de la situation en France

\author{
Mots-clés : \\ Proterorhinus \\ semilunaris, \\ Neogobius \\ melanostomus, \\ Ponticola \\ kessleri, \\ espèces \\ invasives, \\ bassin du Rhin
}

Trois des quatre espèces de gobiidés non natifs actuellement signalées dans le bassin du Rhin ont atteint sa partie française : le gobie demi-lune en 2007, le gobie de Kessler en 2010 et le gobie à tache noire en 2011. Le gobie de Kessler et le gobie à tache noire ont fait preuve d'une vitesse de colonisation très rapide suggérant une migration facilitée par la navigation. L'évaluation du potentiel invasif par la méthode FISK (Fish Invasiveness Screening Kit) révèle un risque moyen pour le gobie demi-lune tandis que le gobie de Kessler et le gobie à tache noire présentent un risque élevé de devenir envahissants en France. Cette évaluation est conforme à nos observations d'une progression constante de l'aire de répartition du gobie demi-lune, bien qu'en faible effectif, tandis que les abondances relatives du gobie de Kessler et du gobie à tache noire, arrivés récemment dans la partie française du Rhin et de la Moselle, peuvent être importantes. Compte tenu de leur rapide progression, on peut supposer que ces espèces coloniseront à court terme d'autres bassins français, en particulier en direction du sud (bassin du Rhône) et de l'ouest (bassin de la Seine) et la mise en place de mesures destinées à en limiter la propagation devrait donc être envisagée.

(1) ONEMA, Office National de l'Eau et des Milieux Aquatiques (The French National Agency for Water and Aquatic Environments), 5 Square Félix Nadar, 94300 Vincennes, France

* Corresponding author: samuel.dembski@onema.fr 


\section{INTRODUCTION}

River basins in Western Europe were depopulated after the quaternary glaciations. Since then, human activities have modified freshwater habitats (e.g. dams, impoundment, canalisation, etc.) and enhanced species dispersal through international trade (e.g. waterways, ship ballasts), resulting in the colonisation of Western basins by species from the Ponto-Caspian basins, one of the main refuge regions during glaciations (Bij de Vaate et al., 2002). As a consequence, we have been seeing the colonisation of non-native species such as pikeperch Sander lucioperca (Linnaeus, 1758), wels catfish Silurus glanis (Linnaeus, 1758) and asp Aspius aspius (Linnaeus, 1758). More recently, Western Europe has faced the colonisation of non-native freshwater goby species and especially the Western tubenose goby Proterorhinus semilunaris (Heckel, 1837), the round goby Neogobius melanostomus (Pallas, 1814) and the bighead goby Ponticola kessleri (Günther, 1861).

The Western tubenose goby is native to the Black Sea basins and east of the Aegean Sea (Kottelat and Freyhof, 2007). The first signs of spread were observed around 1970 when it went up the Danube River up to Linz (Ahnelt et al., 1998), reaching Germany in 1985 (Harka and Biro, 2007), and finally joining the Rhine basin in 1999 (Figure 1a), in the Main River (Reinartz et al., 2000; Schadt, 2000) probably using the Main-Danube Canal built in 1992. The Western tubenose goby was the first one to reach the French part of the Rhine in 2007 (Manné and Poulet, 2008), after reaching the Netherlands in 2002 (Kottelat and Freyhof, 2007). Now, it is recorded in the Meuse basin up to Lixhe (Cammaerts et al., 2012).

The bighead goby is native to the Danube, Dniestr, South Bug and Dniepr drainages (Kottelat and Freyhof, 2007). According to Simonovic et al. (2001), it started expanding upstream of the Danube River around 1992: it was identified 20 km downstream of Vienna in 1994 (Zweimuller et al., 1996), in Slovakia in 1996 (Stranaï, 1998), then in Germany (near Straubing) in 1999 (Seifert and Hartmann, 2000). The bighead goby joined the Rhine basin in 2005 (Figure 1b), probably using the Main-Danube Canal (Kottelat and Freyhof, 2007) as did Proterorhinus semilunaris. It was reported in the Rhine upstream of Bonn in 2006 (Staas, pers. comm.) and in the Netherlands in 2007 (Van Kessel et al., 2011). It reached the Neckar and the Rhine at Mannheim in 2009 (Hartmann, 2010), Baden-Würtemberg in 2010 and was recorded for the first time in Switzerland in Basel (Staub, pers. comm.) in 2011.

Unlike the first two species, the native range of the round goby consists of the littoral zone of the Black Sea, Sea of Azov and the Caspian Sea, as well as estuaries and sometimes lower parts of the rivers Danube, Dniestr, Dniepr, Don and Ural (Kottelat and Freyhof, 2007). In the Danube basin, the historical limit of its distribution was located in Vidin in Bulgaria (Smirnov, 1986). It then moved upstream and was recorded for the first time in Serbia in 1997 (Simonovic et al., 1998), in Vienna in 2000 (Wiesner et al., 2000), near Budapest in Hungary in 2001 (Guti et al., 2003), in Slovakia in 2003 (Stranaï and Andreji, 2004), in Germany in 2004 (Kottelat and Freyhof, 2007), and finally, in the Sava River in Croatia in 2011 (Piria et al., 2011). The round goby reached the Baltic Sea by the Gulf of Gdansk in June 1990 (Skora and Stolarski, 1993) and the German part of this sea in 2002 (Kottelat and Freyhof, 2007). The round goby was recorded in the Rhine delta for the first time in 2004 (van Beek, 2006) (Figure 1c). Later, it was reported in Germany between Düsseldorf and Cologne in 2008 (Staas, pers. comm.) and upstream of the confluence with the Neckar in 2010 (Hartmann, 2010). Further west, it expanded into the basin of the Scheldt and into the Albert Canal in Belgium in 2010 (Verreycken et al., 2011) and nowadays is about to reach the Meuse basin up to Maastricht via this canal.

This article aims to describe the recent colonisation of the Rhine basin, especially in the French part, by the Western tubenose goby, the round goby and the bighead goby, and to assess the potential invasiveness of these species. 


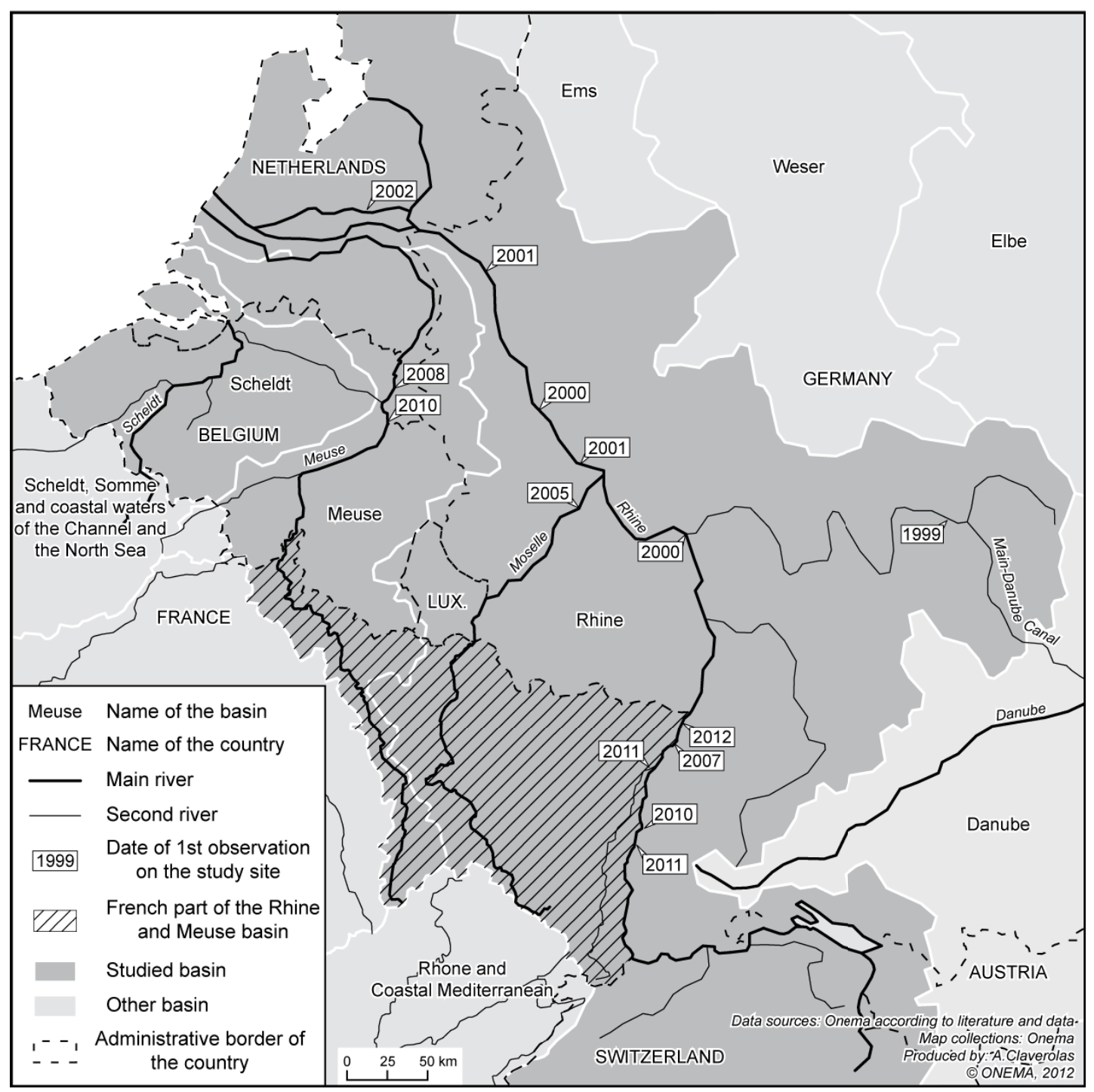

(a)

\section{Figure 1}

Range expansion of Proterorhinus semilunaris (a) Ponticola kessleri (b) and Neogobius melanostomus (c) in the basins of the Rhine, Meuse and Scheldt (see details in the text). Data are combined from the literature and our personal data.

\section{MATERIALS AND METHODS}

Colonisation by gobies was monitored mainly using data from electrofishing, but also observations at fishways and information from anglers (Table I). Electrofishing is mostly performed by The French National Agency for Water and Aquatic Environments (ONEMA) under the Water Framework Directive surveillance monitoring implemented in 2007. Sites within the surveillance monitoring programme are usually sampled every two years in late summer. Some of them are also surveyed annually as part of a national monitoring network initiated in 1995. The sampling method used is a fractional strategy inspired by point abundance sampling (Nelva et al., 1979; Persat and Copp, 1990; ONEMA, 2012) and follows the recommendations of the European Committee for Standardisation's standard (CEN, 2003). Fish were identified to the species level, counted, measured and then released back into the river. When fish were anaesthetised to facilitate handling, they were first stored in water tanks before 


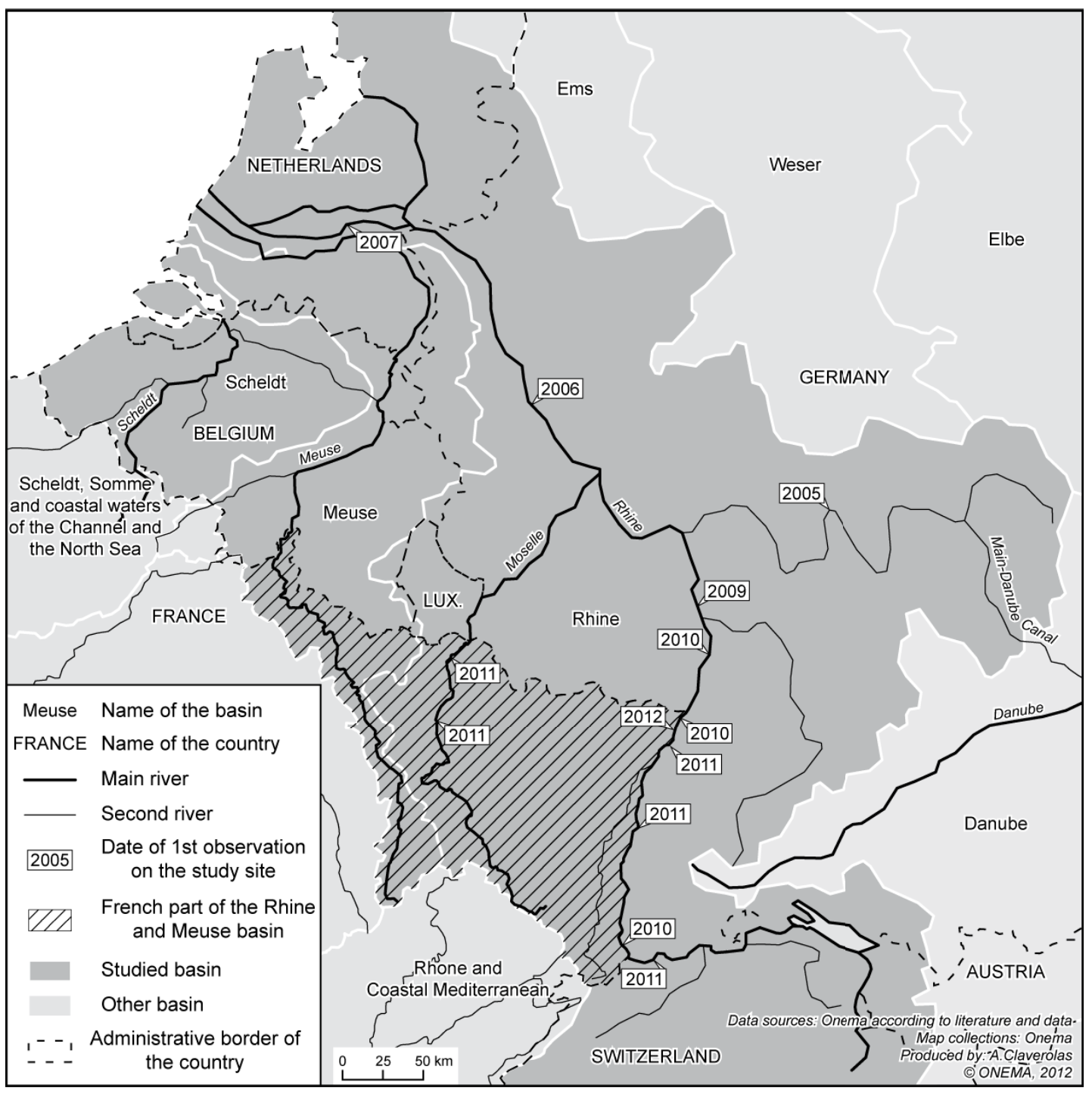

(b)

Figure 1

Continued.

release. Observations of small species in the fishway located at Gambsheim on the Rhine were possible from 2008 to 2012 thanks to annual drains. At the Kembs fishway, a monthly count by draining some pools has been conducted since 1989. The fish were caught, counted and measured. Further information gathered from anglers complemented the previous data.

The total river length colonised in the Rhine basin was measured for each species from their first appearance (i.e. the confluence of the Main-Danube canal and Rhine River for the Western tubenose goby and bighead goby and the Rhine delta for the round goby) and their most extreme locations on the Rhine basin and neighbouring basins. The rate of range expansion was calculated as the total river length colonised divided by the number of years since the arrival of the species. Following the same procedure, the upstream and downstream rates of range expansion along the Rhine River were also calculated.

To assess the invasiveness potential of the Western tubenose goby, the round goby and the bighead goby, a pre-introduction screening tool, the Fish Invasiveness Screening Kit (FISK) (Copp et al., 2009) was used. It is composed of 49 questions in eight categories: (1) domestication, (2) climate and distribution, (3) invasive elsewhere, (4) undesirable traits, (5) feeding 


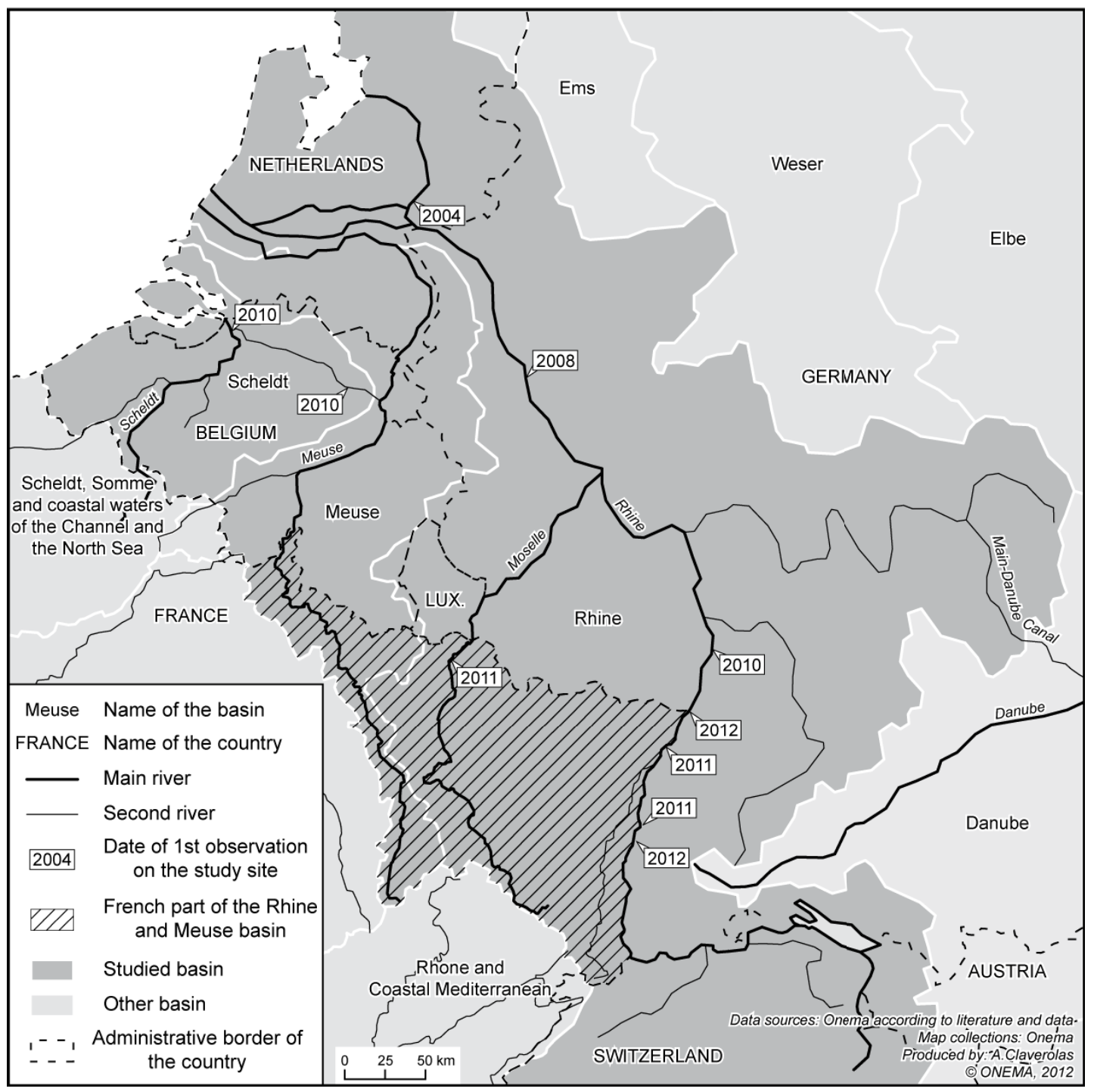

(c)

Figure 1

Continued.

guild, (6) reproduction, (7) dispersal mechanisms, and (8) persistence attributes. Moreover, it takes into account the confidence (certainty/uncertainty) ranking of the assessors, ranging from 4 (= very certain) to 1 (= very uncertain). Assessments were carried out by a single assessor (N.P.) using the calibrated version of the FISK (v2.03), which is freely available for download (Lawson et al., 2012). The critical thresholds for categorising fish species as low, medium or high risk of being invasive have been calibrated by Copp et al. (2009), whereby scores $<1$ indicate low risk, scores of 1 to 18.9 indicate medium risk, and scores of $\geqslant 19$ (to a maximum of 54) indicate high risk.

\section{RESULTS}

From 1999 to 2012, the Western tubenose goby colonised about $1020 \mathrm{~km}$ : that is a rate of range expansion of $73 \mathrm{~km} \cdot$ year $^{-1}$. Since its first capture in France in 2007, it has expanded upstream of the main drain of the Rhine, but also into related branches and the downstream 


\section{Table I}

Description of sites sampled from 1987 to 2012 in the French part of the Rhine-Meuse basin.

\begin{tabular}{|l|c|c|c|}
\hline site No. & name of sampling site & sampling method & years of observation \\
\hline $\mathbf{1}$ & Rhine at Lauterbourg & electrofishing & $2008,2010,2012$ \\
\hline $\mathbf{3}$ & $\begin{array}{c}\text { Rhine between Munchhausen } \\
\text { and Gambsheim }\end{array}$ & angling & 2011 \\
\hline $\mathbf{4}$ & Rhine at Gambsheim & electrofishing & $1987-2012$ \\
\hline $\mathbf{5}$ & Rhine at Gambsheim & drain of fishway & $2008-2012$ \\
\hline $\mathbf{6}$ & Rhine at Rhinau & electrofishing & $1987-2012$ \\
\hline $\mathbf{7}$ & Old Rhine at Sundhouse & electrofishing & $1987-2012$ \\
\hline $\mathbf{8}$ & Schaftheu at Schoenau & electrofishing & $1987-2012$ \\
\hline $\mathbf{9}$ & Old Rhine at Hombourg & electrofishing & $1996-2007,2009,2011$ \\
\hline $\mathbf{1 0}$ & Old Rhine between Niffer and Kembs & electrofishing & 2011 \\
\hline $\mathbf{1 1}$ & Old Rhine at Kembs & drain of fishway & $1989-2012$ \\
\hline $\mathbf{1 2}$ & III at La Wantzenau & electrofishing & $1993-2007,2009,2011$ \\
\hline $\mathbf{1 3}$ & Ill at Osthouse & electrofishing & $1993-2012$ \\
\hline $\mathbf{1 4}$ & Sarre at Grosbliederstroff & electrofishing & $2008,2010,2012$ \\
\hline $\mathbf{1 5}$ & Moselle at Berg/Moselle & electrofishing & $1993-2012$ \\
\hline $\mathbf{1 6}$ & Moselle at Koenigsmacker & angling & 2011 \\
\hline $\mathbf{1 7}$ & Moselle at Metz & angling & 2011 \\
\hline $\mathbf{1 8}$ & Moselle at Champey/Moselle & electrofishing & $1998-2007,2009,2011$ \\
\hline $\mathbf{1 9}$ & Meuse at Givet & electrofishing & $1993-1996,2008,2010,2012$ \\
\hline
\end{tabular}

part of the III River, one of the main tributaries of the Rhine (Figure 1a). The downstream rate of range expansion along the Rhine River was higher $\left(160 \mathrm{~km} \cdot \mathrm{year}^{-1}\right)$ than upstream (38 km.year ${ }^{-1}$ ). For example, each year from 2007 to 2009, the Western tubenose goby was recorded only at Gambsheim (Figures 2a, 2b and 2c), whereas it had colonised the Rhine to the delta in the same time period (Figure 1a). Throughout the period of observation, the Western tubenose goby was captured in low numbers, never exceeding 19 individuals in a sample (Figure 3).

Since its first capture in 2005 in the Main, the bighead goby has colonised $1120 \mathrm{~km}$ : that is a rate of range expansion of $140 \mathrm{~km} \cdot \mathrm{year}^{-1}$. Along the Rhine River, downstream colonisation was faster $\left(210 \mathrm{~km} \cdot \mathrm{year}^{-1}\right)$ than upstream $\left(86 \mathrm{~km} \cdot \mathrm{year}^{-1}\right)$. It was caught for the first time in France in 2010 (Figure 1b), simultaneously at Lauterbourg (Figure 2d) and at the Kembs fishway (Figure 2d), $170 \mathrm{~km}$ upstream. Bighead goby has been caught by anglers frequently and in abundance since 2011 using maggot, soft and metal lures, and with small living fish in the sections of the Rhine and the Moselle River between Metz and the border with Luxembourg (Figure 2e). In our samples, the mean number of individuals and the mean relative abundance of the bighead goby were relatively high (up to $42 \%$ of the total catch in the Rhine at Rhinau in 2011) but have seemed constant since its appearance (Figure 3).

Since its first capture in 2004, the round goby has expanded upstream of the delta in the Rhine, the Scheldt and the Moselle basins $115 \mathrm{~km} \cdot \mathrm{year}^{-1}$ on average (1030 km in total). The upstream rate of range expansion along the Rhine River was about $67 \mathrm{~km} \cdot \mathrm{year}^{-1}$. It was captured for the first time in France in June 2011 (Figure 1c) in the Gambsheim fishway (Figure 2e), then during electrofishing samples performed in late August at Gambsheim and at Rhinau (Figure 2e). Some anglers have also caught it at the Koenigsmacker reach of the Moselle River (Figure 2e). In 2012, the round goby colonised upstream parts of the Rhine (Figure 2f) and was still recorded in the Moselle River, but its numbers and its relative abundance increased dramatically (Figure 3 - up to $45 \%$ of mean relative abundance in 2012) with a maximum of 1094 individuals caught in a single sample in the Rhine at Rhinau (i.e. $84 \%$ of the total catch). 


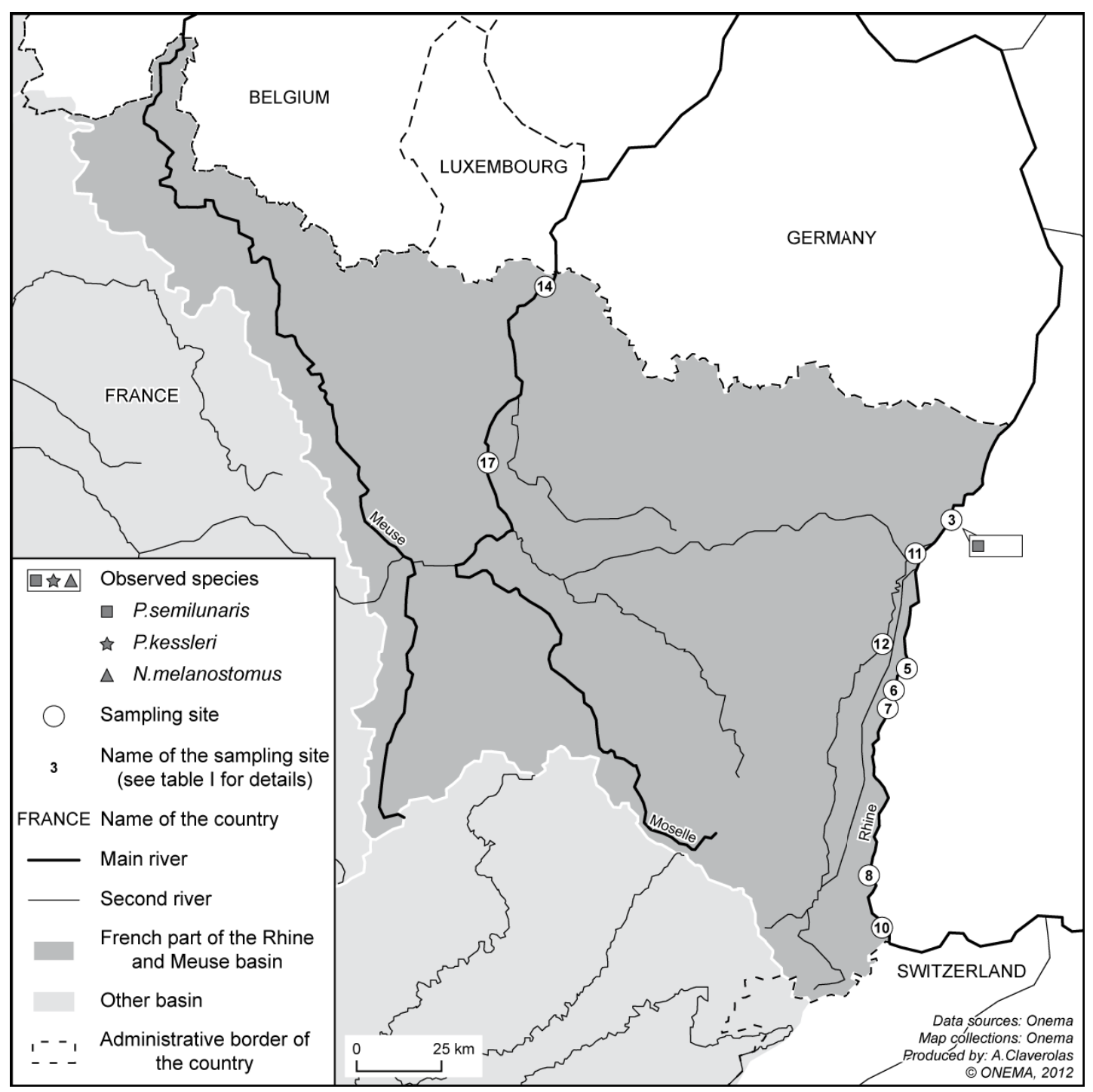

(a)

\section{Figure 2}

Sites where gobies were observed in 2007 (a), 2008 (b), 2009 (c), 2010 (d), 2011 (e) and 2012 (f) in the French part of the Rhine-Meuse basin (the number of each site refers to those listed in Table I).

Using the FISK method, the Western tubenose goby was classified at a medium risk (score $=15$ ), whereas the bighead goby and the round goby were at high risk of becoming invasive (21 and 33, respectively). The frequency of answered questions was $79.6 \%$ for the bighead goby, $87.8 \%$ for the Western tubenose goby and $89.8 \%$ for the round goby. The certainty of the answer was rather high, with a frequency of "very certain" or "certain" of $75.5 \%$ for the Western tubenose goby, $85.7 \%$ for the bighead goby and $87.7 \%$ for the round goby. The lower certainty was observed for the "Undesirable traits", "Dispersal mechanisms" and "Persistence attribute" categories (Figure 4). The unanswered questions concerned the same categories and it is notable that for the bighead goby, $40 \%$ of the questions in the "Invasive elsewhere" category did not have any answers (Figure 4). The main difference between the round goby and the other species appears in the "Biogeography" section (Figure 4) which contains the "Invasive elsewhere" category in which evidence of invasiveness is more common for this species. 


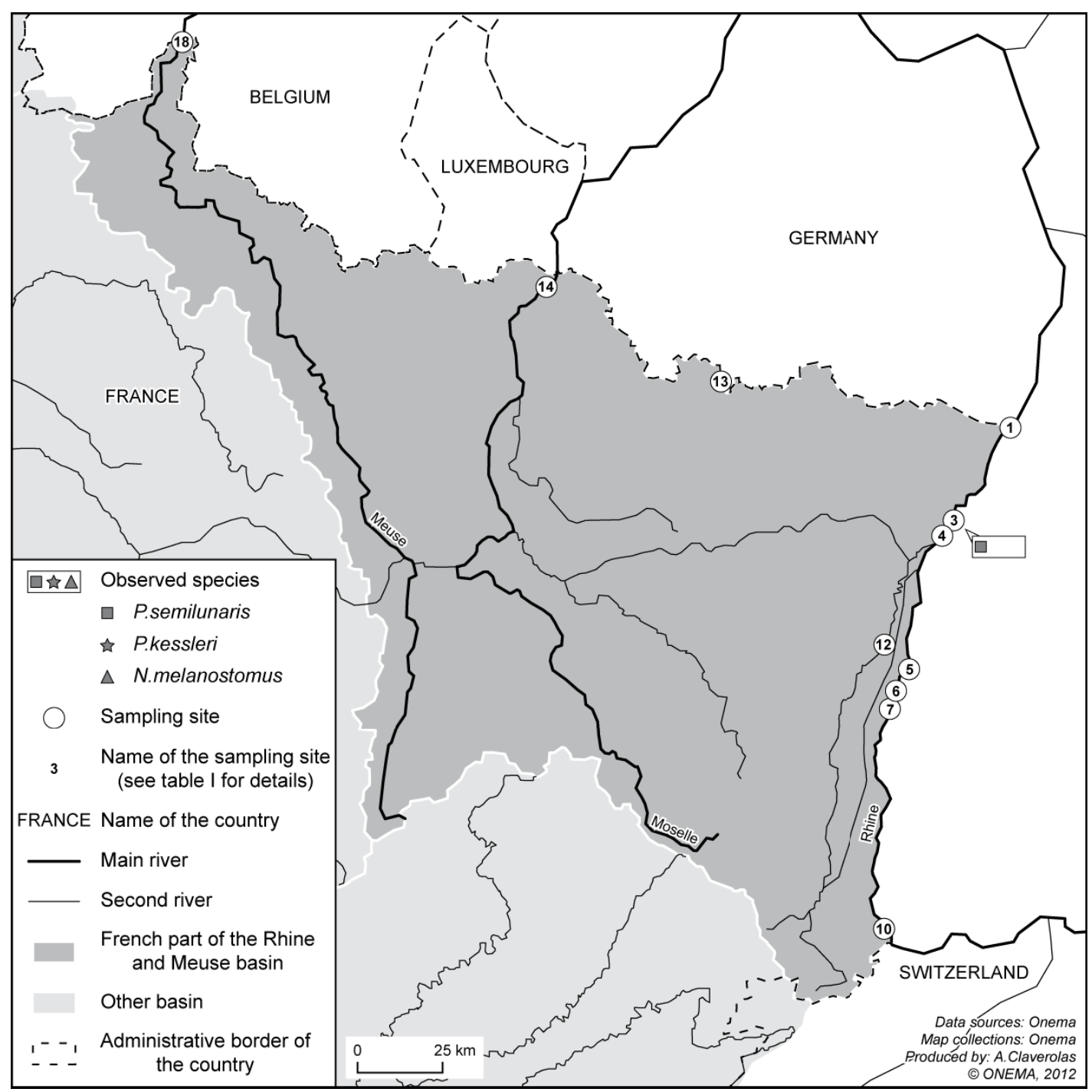

(b)

\section{Figure 2}

Continued.

\section{DISCUSSION}

\section{>RANGE EXPANSION AND DISPERSAL MODES}

Almost 10 years ago, the Western tubenose goby, the round goby, the bighead goby, and the monkey goby Neogobius fluviatilis (Pallas, 1814) started to colonise the Rhine basin and are still expanding nowadays. Their colonisation success implies the existence of introduction pathways from their native ranges. Many authors share the assumption that waterways, connecting the major watersheds together, are the main causes of the biogeographic expansion of many exotic species, and in particular the gobies (Rahel, 2007). Thus, Cammaerts et al. (2012) suggested that the arrival of the Western tubenose goby in the Meuse basin was possible thanks to the Waal-Meuse canal.

Ballast water disposal and hull fouling may also have facilitated and accelerated the spread of gobies (Ahnelt et al., 1998; Roche et al., 2013) such as, for example, the colonisation of the Rhine delta by the round goby (Borcherding et al., 2011), and the colonisation of the North American Great Lakes by the Western tubenose goby and the round goby 


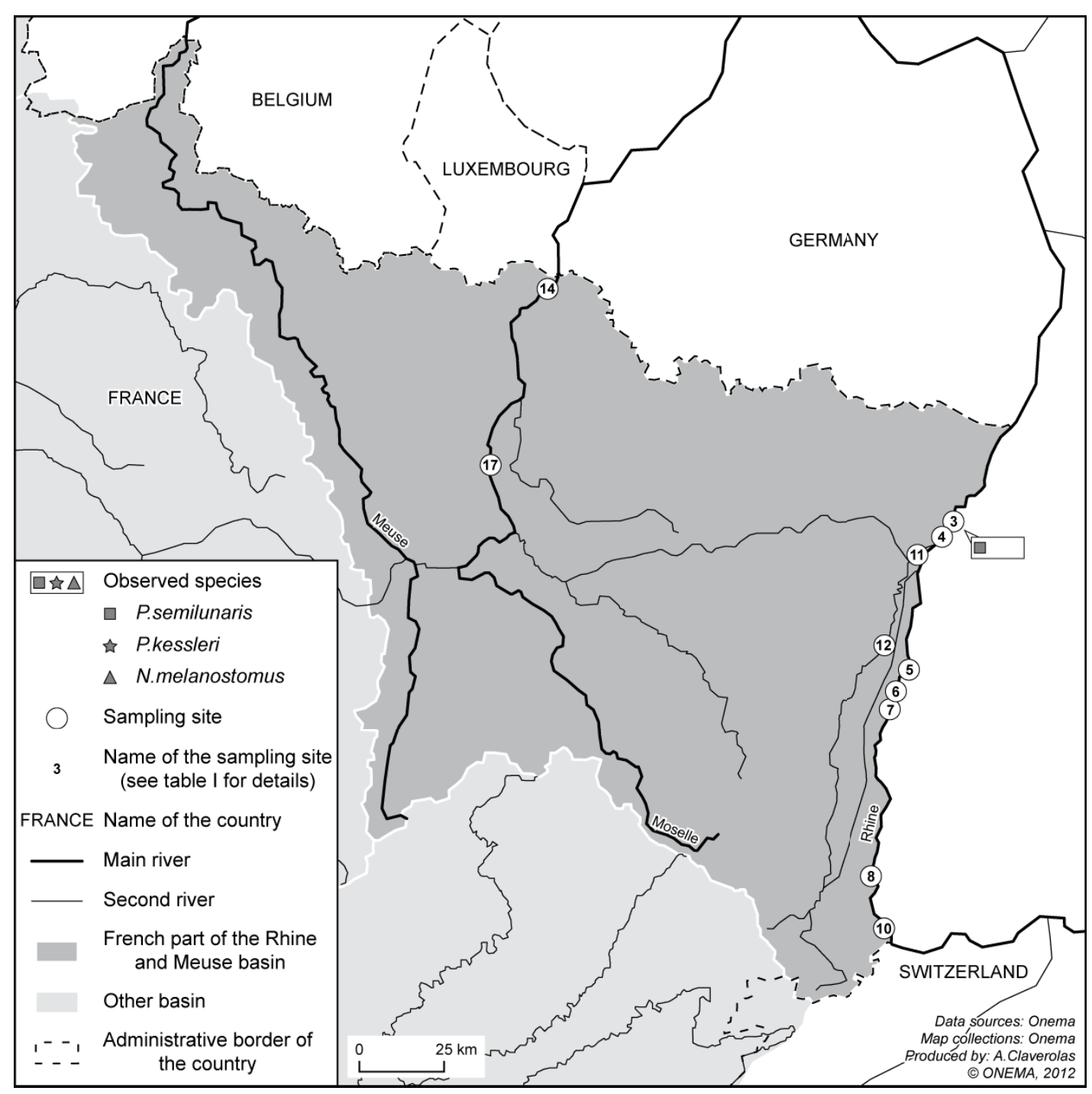

(c)

Figure 2

Continued.

(Corkum et al., 2004). Vessels navigating the Rhine River in France are mostly equipped with double hulls which also serve as ballast (Voies Navigables de France, pers. comm.). As filling is provided by powerful pumps and water intakes are located in the lower part of the hull, benthic species such as gobies can be easily captured and then released later during ballast water discharges. Dispersal through inland navigation may explain the discontinuous upstream expansion of the bighead goby in the Upper Rhine. Indeed, it was first captured both at Lauterbourg and Kembs in 2010, while no catch occurred between these two localities. We suspect a similar pattern for the French part of the Moselle River since the bighead goby was captured at Berg-sur-Moselle in 2011 but not downstream in Luxembourg despite an electrofishing operation performed in Hettermillen the same year.

This hypothesis of human-assisted migration could also explain the high rate of range expansion observed, especially for the bighead goby and the round goby. Indeed, Browscombe and Fox (2012) found that highly mobile round goby individuals may actively move upstream $27 \mathrm{~km} \cdot \mathrm{year}^{-1}$ which is far lower than the upstream rate or range expansion found in the present study for the bighead goby and the round goby (i.e. 86 and $67 \mathrm{~km} \cdot \mathrm{year}^{-1}$, respectively). Of course, our results are rough estimates and probably overestimates as they 


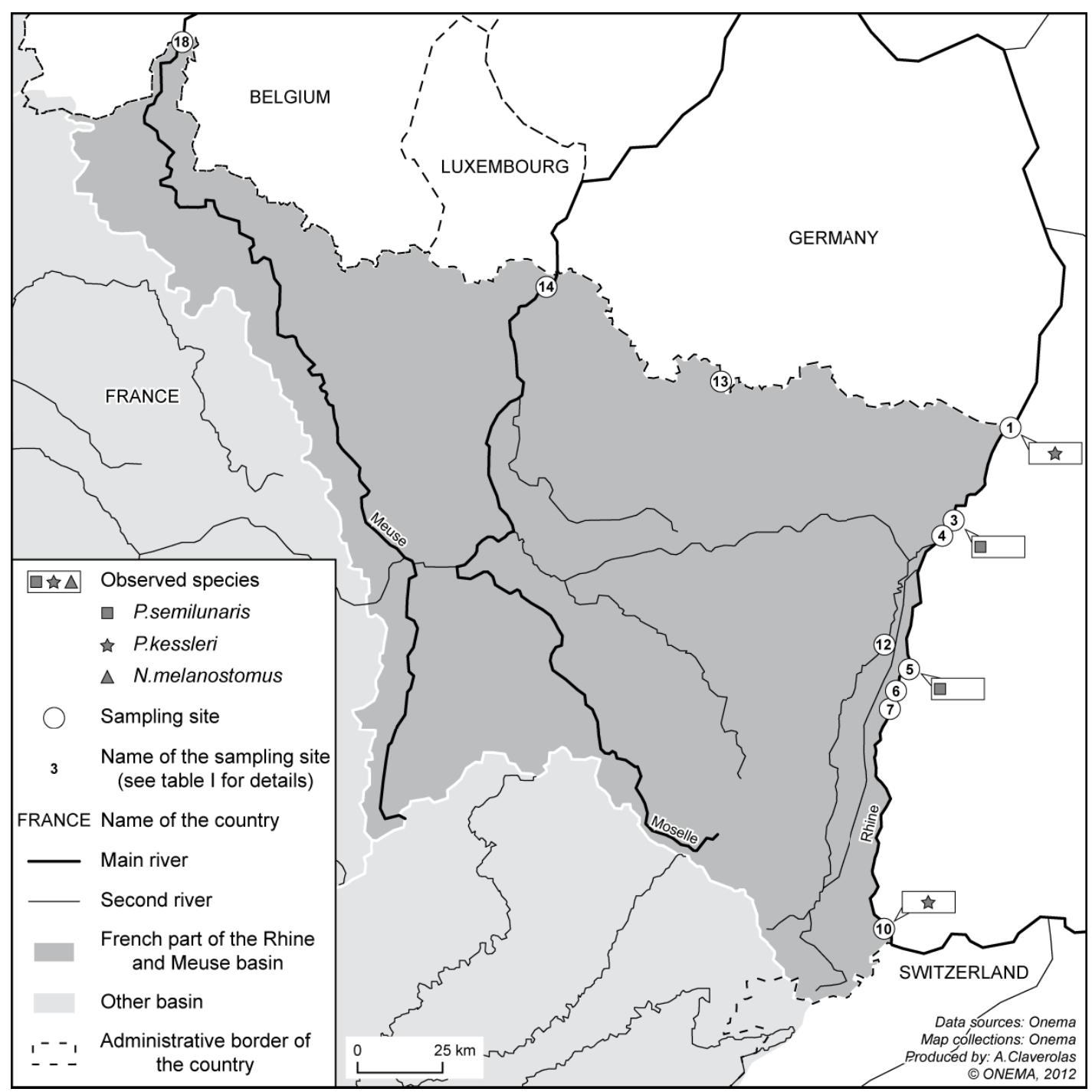

(d)

\section{Figure 2}

Continued.

are not based on very precise time/space scale surveys. Furthermore, when the number of individuals is low at the beginning of the colonisation, the probability of detection is weak. However, the monitoring in the French part of the Rhine basin was fair (from 6 to 10 sites per year for $188 \mathrm{~km}$ of river length) and a methodological bias cannot explain both the large difference with Browscombe and Fox (2012) and the high difference in the rate of range expansion between the Western tubenose goby on one hand, and the bighead goby and the round goby, on the other hand. One could suggest introductions through different pathways but to our knowledge there is no evidence of other ways of dispersal such as anglers, aquaculture, aquariology, etc. Our results suggest that the bighead goby and the round goby have been moved by ships; further investigations can be carried out to specify what stages (adults, larvae or eggs) are transported.

In addition to this dispersal mode, colonisation by active swimming may also occur on a small scale. Verreycken et al. (2011) did not exclude the hypothesis of an active colonisation of the Scheldt River by the round goby through the Rhine-Scheldt canal, as Von Landwust (2006) suggested for the colonisation of the lower part of the Moselle River by the Western tubenose goby. The relatively slow expansion of the latter species in the French part of the 


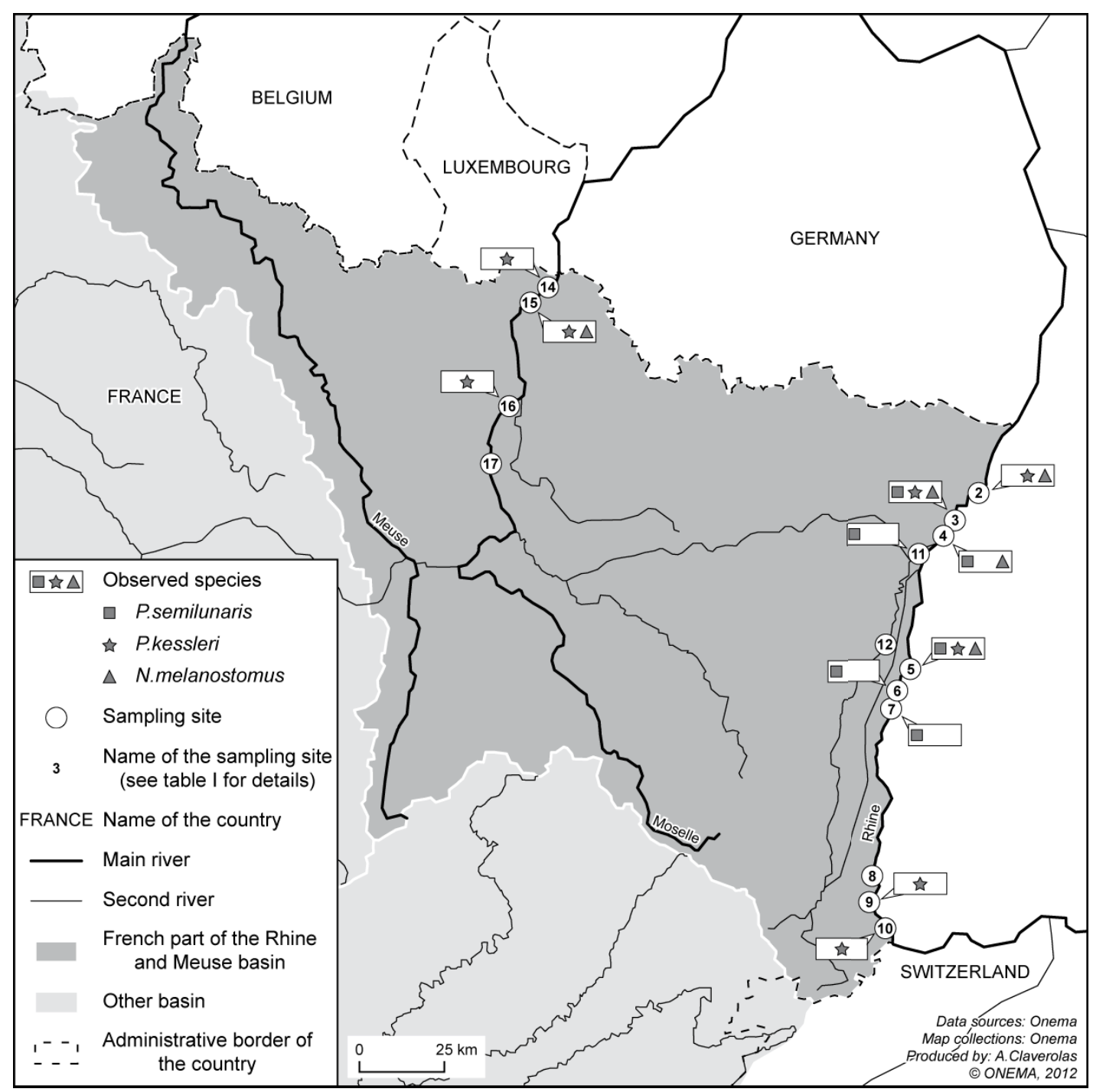

(e)

\section{Figure 2}

Continued.

Rhine between 2007 and 2012 suggests colonisation by natural dispersal. In accordance with this hypothesis, the rate of range expansion of the Western tubenose goby in the present study was clearly lower than for the other species. Tierney et al. (2011) stated that without shelter where the round goby could take refuge, the water velocity must be at least $1.25 \mathrm{~m} \cdot \mathrm{s}^{-1}$ to prevent upstream movement. These results suggest that fishways with successive ponds, those with submerged orifices or rustic fishways, can be traversed by round goby. Finally, for the Western tubenose goby and the bighead goby, colonisation was slower upstream than downstream. This was also observed and explained by larval drift (e.g. Janáč et al., 2013). This is probably the same for the round goby (Hensler and Jude, 2007; Brownscombe and Fox, 2012) but as its colonisation started from the Rhine delta, only upstream expansion was observed.

\section{> INVASIVENESS AND POTENTIAL IMPACT}

In our sampling sites, the Western tubenose goby occurs at low densities and never dominates the community, which is congruent with the observations in the Danube 


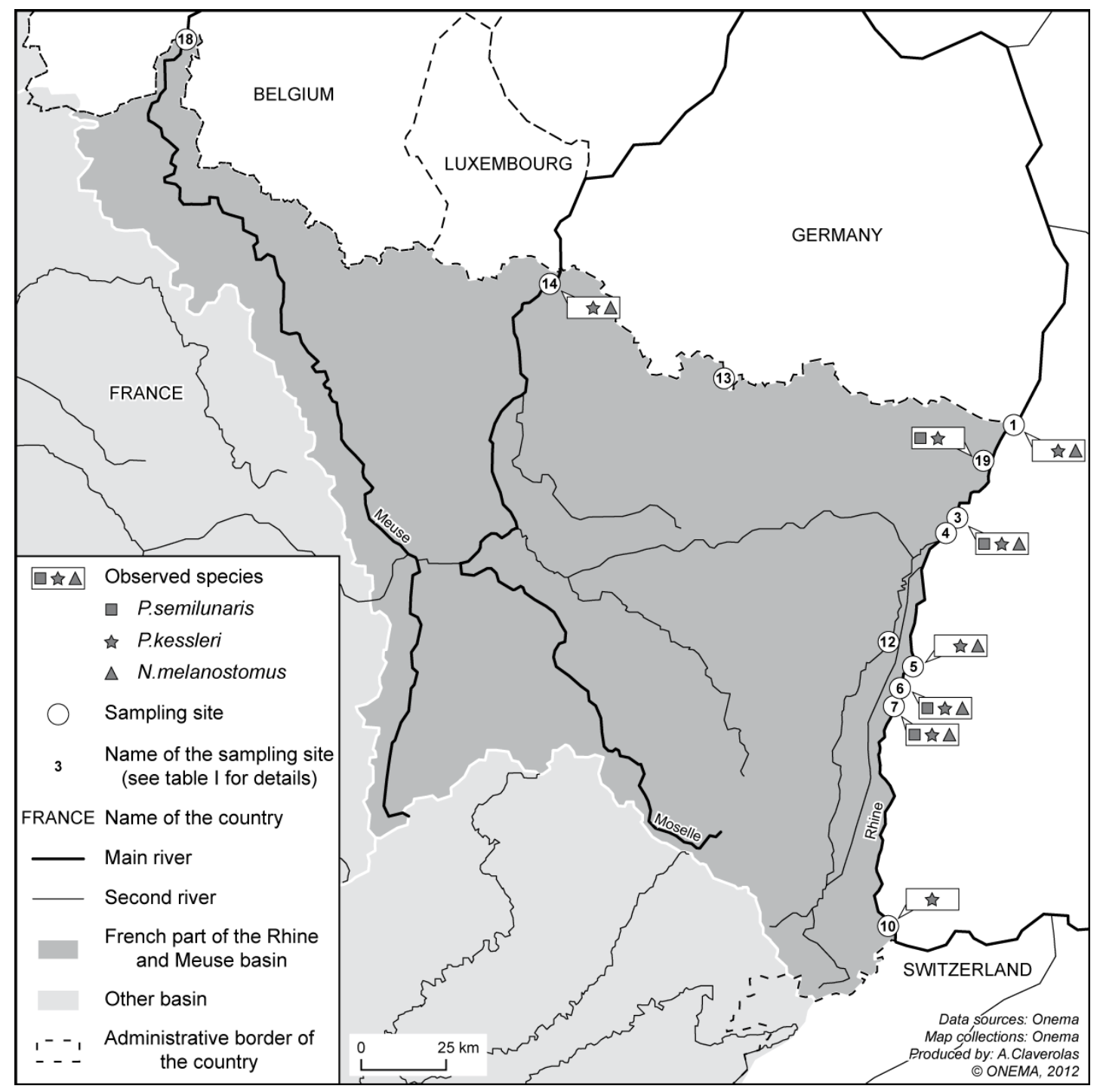

(f)

Figure 2

Continued.

(Eros et al., 2005; Harka and Biro, 2007) and in the lower Rhine (Borcherding et al., 2011). These low abundances imply a lower probability of being pumped up into the ballasts and thus may also explain why, conversely to the two other species, the Western tubenose goby would not have expanded through inland navigation. Conversely, the bighead goby appears to be more abundant not only in the French Rhine but in many locations in its invasive range. The mean relative abundance of the bighead goby over several sampling sites in North RhineWestphalia reached 52\% in late August 2009 and 68\% in early October 2009 (Borcherding et al., 2011). An electrofishing operation conducted in 2011 in Baden-Würtemberg on 200 linear metres of rip-rap led to the capture of 550 bighead gobies (Hartman, pers. comm.), which represents $81 \%$ of the total catch. Also, round goby has been considered to be widespread and abundant in the delta of the Rhine and of the Meuse since its appearance in 2004 (Spikmans and van Kessel, 2010). For some sites sampled in North Rhine-Westphalia, the relative abundance reached $25 \%$ in late August 2009 and $12 \%$ in early October 2009 (Borcherding et al., 2011). According to our results, the relative abundance of round goby 


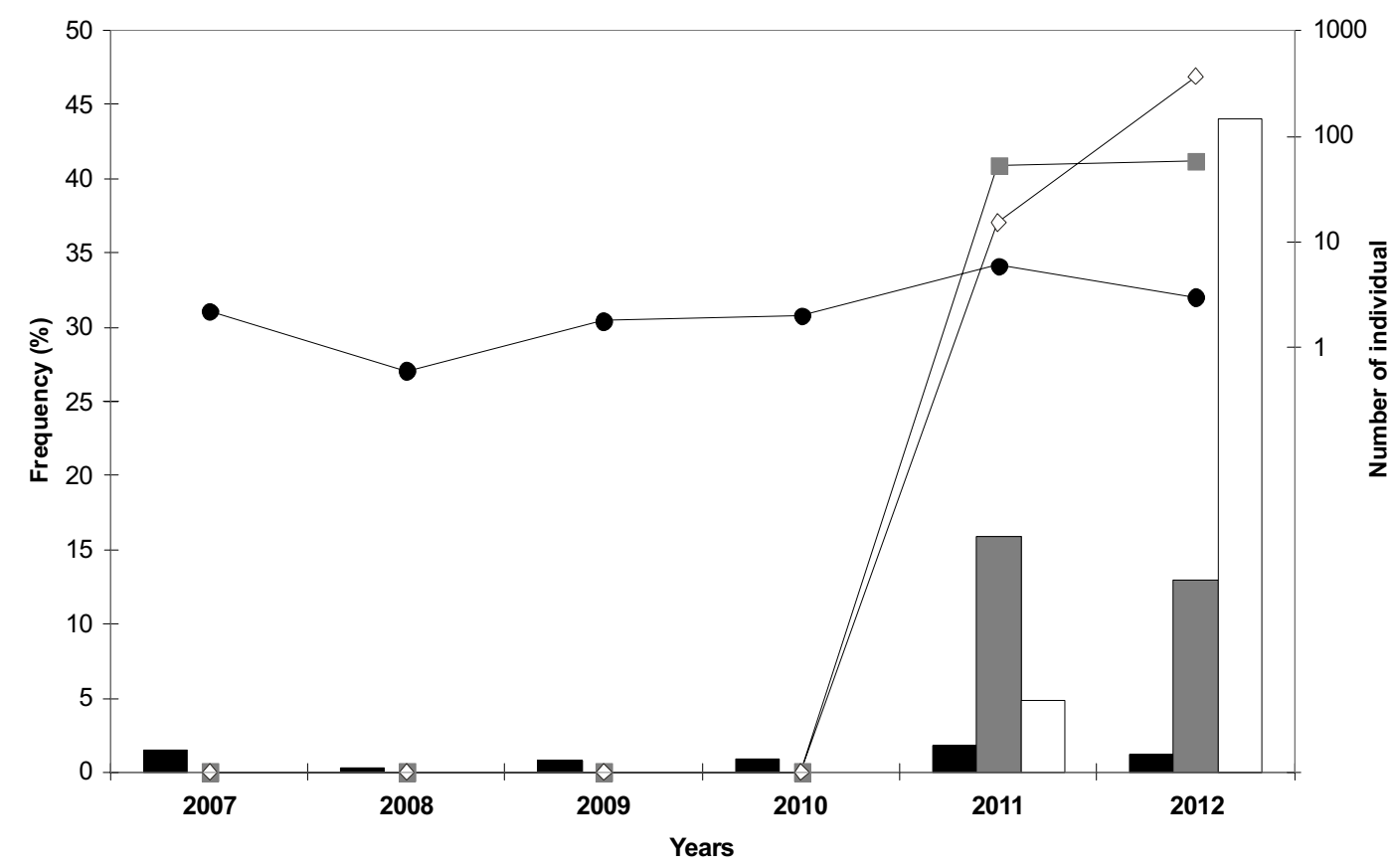

Figure 3

Mean number of individuals (lines) and mean relative abundance (bars) of Proterorhinus semilunaris (black bars and circles), Ponticola kessleri (grey bars and squares) and Neogobius melanostomus (white bars and diamonds) captured in the stations Nos. 3, 5, 6, 7 and 14 from 2007 to 2012.

is high wherever it is captured in the French part of the Rhine basin, exceeding that of the bighead goby.

The risk assessment using the FISK protocol classified the Western tubenose goby at a medium risk and the round goby and the bighead goby at high risk of becoming invasive in France. This classification is in agreement with the evaluations following the same method for the UK (Copp et al., 2009) and for Belgium (Flanders) and Belarus (see Verbrugge et al. 2012) except for the bighead goby in Flanders, which is classified as medium risk. It does not imply that round goby and bighead goby will be invasive in France but they have a great probability of being invasive, and further studies are needed. The main difference among the three species came from what is known about their invasion history. The invasion of the Great Lakes by the round goby allowed a significant increase in the knowledge about this species (e.g. Kornis et al., 2012). The colonisation range of the bighead goby is, for now, more reduced, which can explain why the evidence of its impact on ecosystems is scarcer. Interestingly, the establishment of the Western tubenose goby in the Great Lakes can be explained partly by its high level of genetic diversity (e.g. Stepien and Tumeo, 2006); however, its impact on native species and ecosystem functioning seems difficult to demonstrate (but see Van Kessel et al. 2011). Demonstrating the impact of a species based on circumstantial evidence or opinion is always difficult (for discussion see Gozlan, 2008, Vitule et al., 2009). Furthermore, for the three species some features appear to be poorly studied such as tolerance of extreme conditions (temperature, oxygen) and population dynamics (e.g. dispersal drivers, minimum population size) which are crucial to anticipate invasions.

Among the three species, the Western tubenose goby seems to be the least alarming as a potential invasive species but "medium risk" does not mean "no risk". Indeed, Van Kessel et al. (2011) showed that Cottus perifretum (Freyhof, Kottelat \& Nolte, 2005) displayed a significant shift in habitat choice in co-occurrence with the Western tubenose goby. Since its arrival in the French part of the Rhine in 2007 , there has appeared to be no major change in species composition at the monitoring sites, although further analyses are required. Consistent with our results, the Western tubenose goby never reached high abundances despite its widespread occurrence. Thus, Borcherding et al. (2011) consider this species no longer a significant threat 


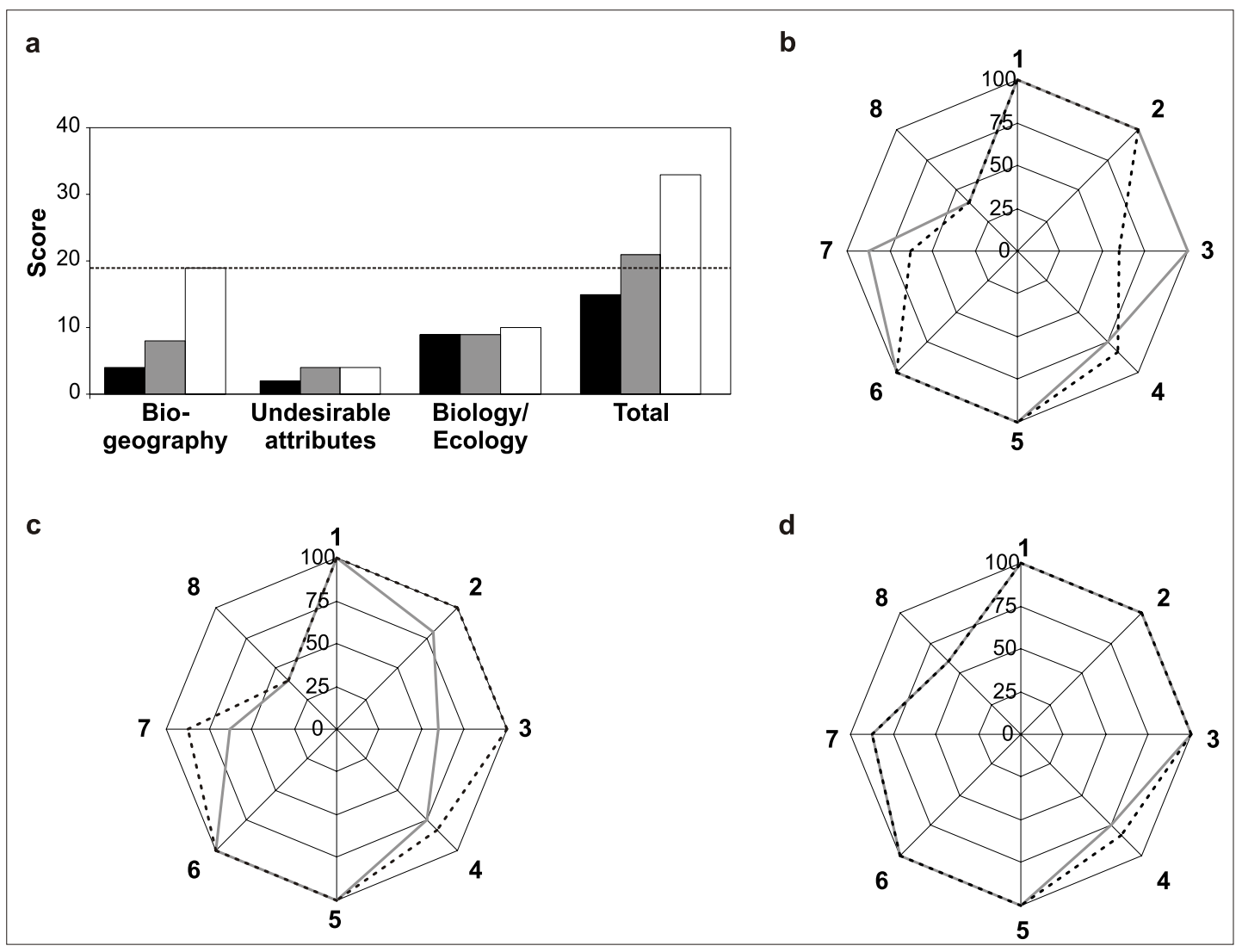

Figure 4

FISK scores (a) total and for each section: "Biogeography" (categories 1, 2 and 3), "Undesirable attributes" (category 4) and "Biology/Ecology" (categories 6, 7 and 8). Proterorhinus semilunaris (black bars), Ponticola kessleri (grey bars) and Neogobius melanostomus (white bars). The dashed line figures the value (19) at which the species is considered at "high risk". Frequency of answered questions (dotted line) and frequency of "very certain" or "certain" answers (grey line) for Ponticola kessleri (b), Proterorhinus semilunaris (c) and Neogobius melanostomus (d) for each FISK category (see text for details).

to native communities in the Lower Rhine. However, according to Spikmans et al. (2010), the Western tubenose goby shows very high densities (over 100 specimens per 100 m electrofishing), e.g. in the Border Meuse (the Netherlands and Belgium). While in the last few years the expansion rate seems to have slowed down in Dutch large rivers, it has steadily increased in slower flowing rivers and stagnant waters and thus its invaded area has hugely increased. In the Great Lakes where the Western tubenose goby was introduced, no evidence of impact was found except a diet overlap with native species (Fuller et al., 2012). Trends are different for the two other species of gobies recently arrived in France, especially for the round goby, whose impacts have been well studied (review in Kornis et al., 2012). Their densities in the Rhine can be high (up to $14 \%$ and $45 \%$ of mean relative abundance for bighead goby and round goby, respectively, according to our results).

The expansion of the Western tubenose goby, bighead goby and round goby is likely to continue in the major rivers of eastern France, then through canals; for example, in other French basins such as the Seine or the Rhône, which could be colonised next. In France, the Meuse basin is about to be colonised by the round goby via the Albert Canal in Belgium. It is already colonised by the Western tubenose goby up to Maastricht. Moreover, other gobiids are likely to reach the French part of the Rhine in the medium term. For example, the monkey goby Neogobius fluviatilis was recorded in the Netherlands in 2009 (Van Kessel et al., 2011) before reaching the lower Rhine in Germany the same year (Borcherding et al., 2011). 
Just like the sharp decline in several populations of native benthic species after the arrival of the round goby in the Great Lakes (Corkum et al., 2004), the arrival of the Ponto-Caspian gobies in France could have similar consequences. For example, the bighead goby has a significant negative influence on the habitat choice of Cottus perifretum (Van Kessel et al., 2011), like the Western tubenose goby, and is known to be an important predator of other gobiids (Banarescu, 1964; Miller, 1986).

Maintaining a monitoring network is very useful for early detection and following invasion patterns. A first risk assessment pointed out a high probability of invasion, at least for bighead goby and round goby. However, the Western tubenose goby must remain on the 'watch list'. It also underlined the lack of knowledge about some ecology features and requested further studies. However, in Belgium, a decree is being prepared to prohibit the possession and transport of live specimens of round gobies (Verreycken et al., 2011). As a precautionary measure, a similar action in France and also in the other countries within the Rhine basin (which is the gate toward the other French basins) should be considered to limit the spread of these species.

\section{ACKNOWLEDGEMENTS}

We wish to thank all the ONEMA agents of the Bas-Rhin, Haut-Rhin and Moselle units for their help during fish samplings. We are also grateful to Amandine Claverolas for map-making and to the Saumon-Rhin Association and Dubost Environnement et Milieux Aquatiques for giving us additional information. Gordon $\mathrm{H}$. Copp and Lorenzo Vilizzi kindly gave us useful advice on the use of the FISK. We thank the two anonymous referees for their helpful comments on the manuscript and Guillaume Tixier for linguistic advice.

\section{REFERENCES}

Ahnelt H., Bănărescu P., Spolwind R., Harka Â. and Waidbacher H., 1998. Occurrence and distribution of three gobiid species (Pisces, Gobiidae) in the middle and upper Danube region - examples of different dispersal patterns? Biologia, Bratislava, 53, 665-678.

Banarescu P., 1964. Pisces - Osteichthyes [in Rumanian]. Fauna R.P. Romine. Academiei Republicii Populare Romine, Bucuresti, 959.

Bij de Vaate A., Jazdzewski K., Ketelaars H.A.M., Gollasch S. and Van der Velde G., 2002. Geographical patterns in range extension of Ponto-Caspian macroinvertebrate species in Europe. Can. J. Fish. Aquat. Sci., 59, 1159-1174.

Borcherding J., Staas S., Kruger S., Ondrackova M., Slapansky L. and Jurajda P., 2011. Non-native Gobiid species in the lower river Rhine (Germany): recent range extensions and densities. J. Appl. Ichthyol., 27, 153-155.

Brownscombe J.W. and Fox M.G., 2012. Range expansion dynamics of the invasive round goby (Neogobius melanostomus) in a river system. Aquat. Ecol., 46, 175-189.

Cammaerts R., Spikmans F., van Kessel N., Verreycken H., Chérot F., Demol T. and Richez S., 2012. Colonization of the border Meuse area (The Netherlands and Belgium) by the non-native western tubenose goby Proterorhinus semilunaris (Heckel, 1837) (Teleostei, Gobiidae). Aquatic Invasions, $7,251-258$.

CEN, 2003. Échantillonnage des poissons à l'électricité. AFNOR, 18.

Copp G.H., Vilizzi L., Mumford J., Fenwick G.V., Godard M.J. and Gozlan R.E., 2009. Calibration of FISK, an invasiveness screening tool for nonnative freshwater fishes. Risk Anal., 9, 457-467.

Corkum L.D., Sapota M.R. and Skora K.E., 2004. The round goby, Neogobius melanostomus, a fish invader on both sides of the Atlantic Ocean. Biol. Invasions, 6, 173-181.

Eros T., Sevcsik A. and Toth B., 2005. Abundance and night-time habitat use patterns of Ponto-Caspian gobiid species (Pisces, Gobiidae) in the littoral zone of the River Danube, Hungary. J. Appl. Ichthyol., 21, 350-357. 
Fuller P., Nico L., Maynard E., Neilson M., Larson J. and Fusaro A., 2012. Proterorhinus semilunaris. USGS Nonindigenous Aquatic Species Database, Gainesville, FL.

Gozlan R.E., 2008. Introduction of non-native freshwater fish: is it all bad? Fish and Fisheries, 9, $106-115$.

Guti G., Eros T., Szaloky Z. and Toth B., 2003. Round goby, Neogobius melanostomus (Pallas, 1811) in the Hungarian section of the Danube [in Hungarian]. Halászat, 96, 116-119.

Harka A. and Biro P., 2007. New patterns in Danubian distribution of Ponto-Caspian gobies - A result of global climatic change and/or canalization? Electronic Journal of Ichthyology, 1, 1-14.

Hartmann F., 2010. Meldung: Schwarzmundgrundel (Neogobius melanostomus) in Baden-Württemberg angekommen [in German]. Aquakultur und fischereiinformationen aus unserer fischereiverwaltung, 16.

Hensler S.R. and Jude D.J., 2007. Diel vertical migration of round goby larvae in the Great Lakes. J. Gt. Lakes Res., 33, 295-302.

Janáč M., Šlapanský L., Valová, Z. and Jurajda P., 2013. Downstream drift of round goby (Neogobius melanostomus) and tubenose goby (Proterorhinus semilunaris) in their non-native area. Ecol. Freshwat. Fish., 22, 430-438.

Kornis M.S., Mercado-Silva N. and Vander Zanden M.J., 2012. Twenty years of invasion: a review of round goby Neogobius melanostomus biology, spread and ecological implications. J. Fish. Biol., 80, 235-285.

Kottelat M. and Freyhof J., 2007. Handbook of European freshwater fishes. Kottelat, Cornol and Freyhof, Berlin, $646 \mathrm{p}$.

Lawson L.L., Vilizzi L., Hill J.E., Hardin S. and Copp G.H., 2012. Revisions of the Fish Invasiveness Scoring Kit (FISK) for its application in warmer climatic zones, with particular reference to peninsular Florida. Risk Anal., doi: 10.1111/j.1539-6924.2012.01896.x.

Manné S. and Poulet N., 2008. First record of the western tubenose goby Proterorhinus semilunaris (Heckel, 1837) in France. KMAE 389, 03.

Miller P.J., 1986. Gobiidae. In: Whitehead P.J.P., Bauchot M.L., Hureau J.C., Nielsen J. and Tortonese E. (eds.), Fishes of the North-East Atlantic and the Mediterranean. UNESCO, Paris, 1019-1095.

Nelva A., Persat H. and Chessel D., 1979. Une nouvelle méthode d'étude des peuplements ichtyologiques dans les grands cours d'eau par échantillonnage ponctuel d'abondance [In French]. C.R. Acad. Sci. Paris, 289, 679-791.

ONEMA, 2012. Mise en oeuvre des opérations de pêche à l'électricité dans le cadre des réseaux de suivi des peuplements de poissons [In French]. Guide pratique. Office National de l'Eau et des Milieux Aquatiques, 23.

Persat H. and Copp G.H., 1990. Electric fishing and point abundance sampling for the ichtyology of large rivers. In: Cowx I.G. (ed.), Developments in electric fishing.

Piria M., Sprem N., Jakovlic I., Tomljanovic T., Matulic D.T., Anicic I. and Safner R., 2011. First record of round goby, Neogobius melanostomus (Pallas, 1814) in the Sava River, Croatia. Aquatic Invasions, 6, 153-157.

Rahel F.J., 2007. Biogeographic barriers, connectivity and homogenization of freshwater faunas: it's a small world after all. Fresh. Biol., 52, 696-710.

Reinartz R., Hilbrich T. and Bom O., 2000. Nachweis der Marmorierten Grundel (Proterorhinus marmoratus Pallas, 1811) im unterfränkischen Main bei Eltmann (Rheineinzugsgebiet) [in German]. Österreichs Fischerei, 53, 192-194.

Roche K.F., Janac M. and Jurajda P., 2013. A review of Gobiid expansion along the Danube-Rhine corridor - geopolitical change as a driver for invasion. Knowl. Managt. Aquatic Ecosyst. (in press).

Schadt J., 2000. Neue Fischart im Main entdeckt: Marmorierte Grundel (Proterorhinus marmoratus) [in German]. Fischer \& Teichwirt, 51, 217-218.

Seifert K. and Hartmann F., 2000. Die Kesslergrundel (Neogobius kessleri Günther 1861), eine neue Fischart in der deutschen Donau [in German]. Lauterbornia, 38, 105-108.

Simonovic P., Paunovic M. and Popovic S., 2001. Morphology, feeding, and reproduction of the round goby, Neogobius melanostomus (Pallas), in the Danube River Basin, Yugoslavia. J. Gt. Lakes Res., 27, 281-289.

Simonovic P., Valkovic B. and Paunovic M., 1998. Round goby Neogobius melanostomus, a new PontoCaspian element for Yugoslavia. Folia Zool. , 47, 305-312. 
Skora K.E. and Stolarski J., 1993. New fish species in the Gulf of Gdansk, Neogobius sp. [cf. Neogobius melanostomus (Pallas 1811)]. Bull. Sea Fish. Inst., 1, 83-84.

Smirnov A.l., 1986. Perciformes (Gobioidei), Scorpaeniformes, Pleuronectiformes, Lophiiformes [in Russian]. In: Topachevsky, V.A. (ed.), Fauna Ukrainy, Kijev, 33-57.

Spikmans F. and van Kessel N., 2010. Nuissance/risk analysis and habitat use of exotics in the large river [in Dutch]. 26th Meeting of Vissennetwerk, Bilthoven, the Netherlands.

Spikmans F., van Kessel N., Dorenbosch M., Kranenbarg J., Bosveld J. and Leuven R., 2010. Plaag Risico Analyses van tien exotische vissoorten in Nederland [in Dutch]. Nederlands Centrum voor Natuuronderzoek: Stichting RAVON, Radboud Universiteit Nijmegen, Stichting Bargerveen \& Natuurbalans - Limes Divergens, Nijmegen).

Stepien C.A. and Tumeo M.A., 2006. Invasion genetics of Ponto-Caspian gobies in the Great Lakes: a 'cryptic' species, absence of founder effects, and comparative risk analysis. Biol. Invasions, 8 , $61-78$.

Stranaï I., 1998. Morphometry study on Neogobia kessleri (Günther 1861) from the main stream of the Danube river. Czech J. Anim. Sci., 43, 289-292.

Stranaï I. and Andreji J., 2004. The first report of round goby, Neogobius melanostomus (Pisces, Gobiidae) in the waters of Slovakia. Folia Zool., 53, 335-338.

Tierney K.B., Kasurak A.V., Zielinski B.S. and Higgs D.M., 2011. Swimming performance and invasion potential of the round goby. Environ. Biol. Fish., 92, 491-502.

van Beek G.C.W., 2006. The round goby Neogobius melanostomus first recorded in the Netherlands. Aquatic Invasions, 1, 42-43.

Van Kessel N., Dorenbosch M., De Boer M.R.M., Leuven R.S.E.W. and Van der Velde G., 2011. Competition for shelter between four invasive gobiids and two native benthic fish species. Current Zoology, 57, 844-851.

Verbrugge L.N.H., Van der Velde G., Hendriks A.J., Verreycken H. and Leuven R.S.E.W., 2012. Risk classifications of aquatic non-native species: Application of contemporary European assessment protocols in different biogeographical settings. Aquatic Invasions, 7, 49-58.

Verreycken H., Breine J., Snoeks J. and Belpaire C., 2011. First record of the round goby, Neogobius melanostomus (Actinopterygii: Perciformes: Gobiidae) in Belgium. Acta Ichthyol. Piscat., 41, $137-140$.

Vitule J.R.S., Freire C.A. and Simberloff D., 2009. Introduction of non-native freshwater fish can certainly be bad. Fish and Fisheries, 10, 98-108.

Von Landwust C., 2006. Expansion of Proterorhinus marmoratus (Teleostei, Gobiidae) into the River Moselle (Germany). Folia Zool., 55, 107-111.

Wiesner C., Spolwind R., Waidbacher H., Guttman S. and Doblinger A., 2000. Erstenachweis der Schwarzmundgrundel Neogobius melanostomus (Pallas, 1814) in Österreich [in German]. Österreichs Fischerei, 53, 330-331.

Zweimuller I., Moidl S. and Nimmervoll H., 1996. A new species for the Austrian Danube - Neogobius kessleri. Acta Univ. Carol. Biol., 40, 213-218. 